\title{
SCARE OF AVIAN FLU REVISITS INDIA: A BUMPY ROAD AHEAD
}

\author{
By Rajnish Kumar Rai*
}

\begin{abstract}
With the threat of an avian flu pandemic once again looming over eastern India, issues regarding patents and affordability and accessibility of drugs have taken center stage. The key priority of India should be to remain prepared to address the public health crisis effectively, by stockpiling the drug tamiflu so that it can be easily distributed and administered to the needy.

India had been confronted with a serious threat of avian flu in 2005-06, but past experience shows that, despite having some of the broadest and most comprehensive compulsory patent licensing laws, India's policymaking elite shied away from fully exploiting these legal 'flexibilities.' Fortunately, the danger of avian flu did not turn into a substantial public health crisis that year.

Under this backdrop, this paper explores various 'flexibilities' available in the Indian patent law and suggests short term and long term strategies to effectively tackle the impending danger of an avian flu pandemic, and similar public health crises in future. This paper will discuss potential areas of conflict between the indigenous generic drug firms and the multi-national companies with respect to TRIPS compliance in the event that these flexibilities are exploited. This paper also highlights the administrative constraints and the economic viability of the compulsory licensing system. Finally, this paper shows how political will is often more critical than having well documented provisions in statute books to respond to such situations effectively.
\end{abstract}

\footnotetext{
The author is a senior police officer of the Indian Police Service. The author has a Bachelor of Technology degree in Electronics \& Telecommunication, and post-graduate degrees in personnel management, patent law, and public policy and management from the Indian Institute of Management, Bangalore.

The author would like to thank Professor A. Damodaran and Professor Rupa Chanda and Professor Gopal Naik for their invaluable suggestions for improvement of this paper. The author would also like to express his sincerest gratitude to Dr. GL Telang, Saumil Mody, Roche Scientific Company (India) Pvt. Ltd.; Sree Patel, GlaxoSmithKline; Lobo Yolynd, Pfizer (India) Ltd.; Ranga Iyer, Wyeth Limited; Shirish Ghoge, Yasmin J. Cama, Sanofi Aventis; Amar Lulla, Cipla; Dr. Vijayaraghavan, Ranbaxy; NH Israni, Bluecross Laboratories Ltd.; M. Sirinivas Reddy,Hetero Drugs; Prem Godha, IPCA Laboratories Ltd.; KM Gopakumar, CENTAD; Biswajeet Dhar; Gajanan Wakankar, Executive Director, Indian Drug Manufacturers' Association, Paresh Johri, Deputy Secretary, Ministry of Chemical and Fertilizers for their excellent inputs on this study. The author had interviewed them in 2006 and possesses the transcript of the entire interviews on the file.
}

This paper is an updated version of one aspect of the dissertation submitted in fulfillment of the PGPPM (Post Graduate Program in Public Policy and Management) at IIM, Bangalore. 


\section{Table of Contents}

SCARE OF AVIAN FLU REVISITS INDIA: A BUMPY ROAD AHEAD............... 1

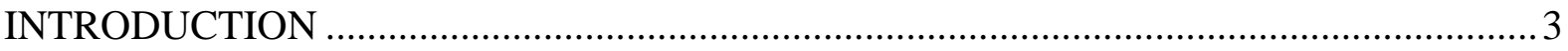

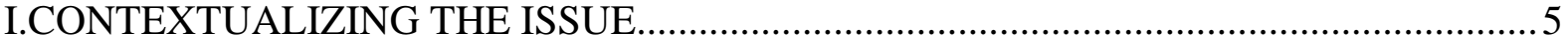

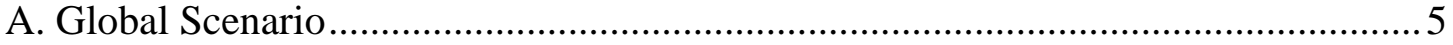

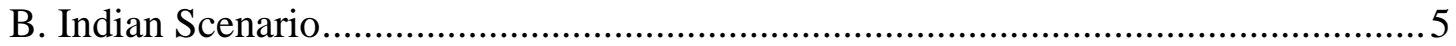

C. Availability of Antiviral Drugs Effective in Treating Avian Influenza .................... 6

II. TAMIFLU'S PATENT DISPUTE AND ITS STATUS IN INDIA .................................

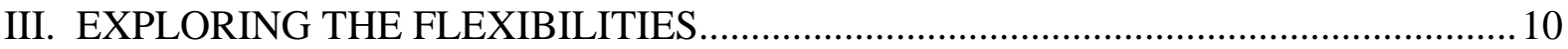

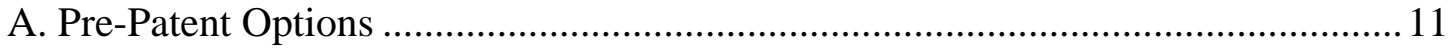

1.Challenge the Mailbox Application by Filing a Pre-grant Opposition ................ 11

2.Prior User Rights vis-à-vis Patents from Mailbox Applications .......................... 12

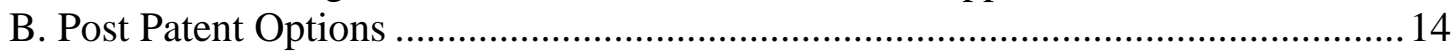

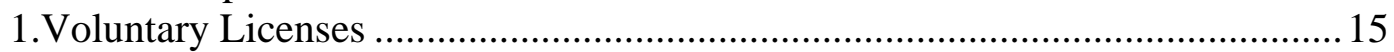

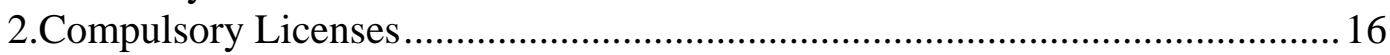

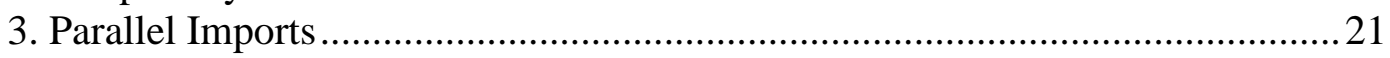

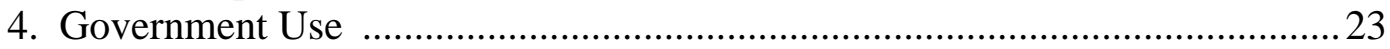

IV. ADMINISTRATIVE FEASIBILITY AND ECONOMIC VIABILITY ......................... 23

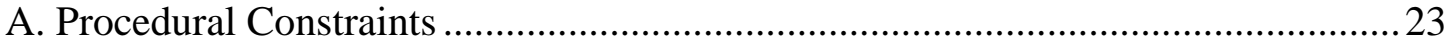

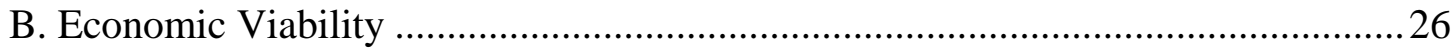

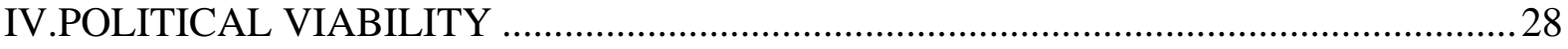

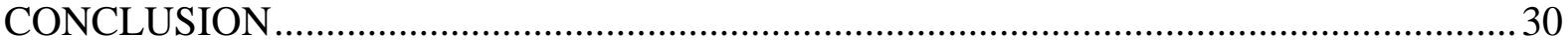




\section{INTRODUCTION}

Recently, the specter of an avian flu pandemic has raised its ugly head again, with reports of new deaths in China, Indonesia, and Vietnam. The first victims to die in South Asia have also been reported. ${ }^{1}$ It has now traveled to West Bengal, an eastern state in India where more than 13 districts have been reported to be affected. If this problem is not nipped in the bud, there is an impending danger of it quickly spreading to adjacent states. While India is currently grappling with national logistical pressures to ward off the threat, the issue of patents, prices, and access to avian influenza treatments has once again come up in the international forums as well as in India.

There is a world of difference between epidemics of influenza and HIV/AIDS regarding the respective public health challenges they pose; they mark the polar ends of a spectrum of complexity in the necessary public health measures to combat them. HIV/AIDS is a prolonged epidemic, infection is surreptitious, healthy persons harbour the virus for life (as of now), and the incubation period is measured in months to years, but it is noncontagious. An epidemic of influenza on the other hand will be short-lived, spread fast and wide, and will disrupt normal societal and institutional functioning. The incubation period and the infectious period are both very short - just a few days. ${ }^{2}$ Hence, we cannot wait for the pandemic to occur as the deadly avian influenza would not give us time for preparation. Therefore, the strategy to counter the threat of avian flu has to be totally different from that of HIV/AIDS and the first step should be to create stockpiles of Tamiflu that can be easily distributed and administered during the pandemic.

India has one of the broadest and most comprehensive compulsory licensing systems, which goes “'much beyond national emergency and extreme[ly] urgent situations, public health cris[e]s and anti-trust situations.",3 Having a well established law in place to exploit

1 See Yu Geoffrey, Avian Flu: Health, Innovation, Intellectual Property, ISN Security Watch, Jan. 10, 2008, available at http://www.isn.ethz.ch/news/sw/details.cfm?ID=18514.

T. J. John, Human Rights and Public Health During Pandemic Influenza, INDIAN JoURNAL OF MEDiCAL ETHICS, Jan-March 2006 14(1), available at http://www.issuesinmedicalethics.org/141ed002.html (last visited January 27, 2008).

Janice M. Mueller, The Tiger Awakens: The Tumultuous Transformation of India's Patent System and the Rise of Indian Pharmaceutical Innovation, 68 U. Pitt. L. Rev. 491, 581 (2007) (quoting Manojit Saha, Drug patent: A viagra for Indian pharmaceutical industry, Deccan Herald (Bangalore, India), Apr. 4, 2005, available at http://www.deccanherald.com/Archives/apr42005/93626200543.asp). 
the flexibilities provided under the Trade-Related Aspects of Intellectual Property Rights (TRIPS) Agreement, Doha Declaration, and August 30 Decision is one thing, but exploiting these flexibilities in practice is another. Past experience during a similar crisis in 2005-06 suggests that the Indian Government appears much more cautious in employing these flexibilities for pharmaceutical patent matters, and has been reluctant to take a decisive stand on the issue. ${ }^{4}$

The objective of this paper is to explore the various flexibilities provided in the TRIPS Agreement and incorporated into India's Patent (Amendments) Act of 2005 (hereinafter referred to as 'the Act') to:

(1) suggest short-term (immediate measures) and long-term strategies that India may adopt to ward off the current crisis, and prepare itself for handling such national emergencies and public health crises in future; and

(2) examine whether it would be administratively feasible and economically viable for the Indian generic pharmaceutical industry to supply drugs and medicines to the countries having insufficient or no capacity to manufacture them themselves. ${ }^{5}$

This paper is organized into five sections. Section I presents a bird's eye view of avian influenza to contextualize the issue at hand. Section II discusses the dispute regarding the patent of Tamiflu (Osteltamivir Phosphate) and the status of the Tamiflu patent in India, and also briefly touches upon the position of Roche, Inc., the producer of Tamiflu. Section III explores the various legal provisions available in India's Patent law that may be employed to address the challenges posed by an avian influenza pandemic. Section III also highlights the differences of opinion between the Indian firms and the multi-national companies (MNCs) with regard to these flexibilities, and the potential disputes that may arise if these flexibilities are exploited. Section IV details the issues relating to 'administrative feasibility' and ‘economic viability’ of these flexibilities. Section V briefly outlines India’s response during

$4 \quad$ See Shamnad Basheer, India's New Patent Regime: Aiding “Access” or Abetting “Genericide”? 9 INT. J. BioteCHNOLOGY 122 (2007).

5 World TRAdE ORgANizATION: DECLARATION ON THE TRIPS AgREEMENT AND PubliC HEALTH, http://docsonline.wto.org/imrd/directdoc.asp?DDFDocuments/t/WT/Min01/DEC2.doc (last visited Apr. 14, 2008). The Decision allowed any country to issue a compulsory license for exports and detailed conditions under which countries may be eligible to import drugs, including the obligations of the exporting countries, importing countries and "generics” manufacturers. WORLD TRADE ORGANIZATION INTELLECTUAL PROPERTY (TRIPS): IMPLEMENTATION OF PARAGRAPH 6 OF THE DOHA DECLARATION ON THE TRIPS AGREEMENT AND PUBLIC HEALTH, http://www.wto.org/english/tratop_e/trips_e/implem_para6_e.htm (last visited Apr. 4, 2008). 
the similar crisis in 2005-06 to highlight the importance of the 'political viability' aspect of employing these flexibilities. The paper concludes with the outline of a strategy that may be adopted by India to address the current crisis, and with the observation that in matters such as these having international ramifications, the political will of the government is more critical for success than merely having laws, rules, and regulations on the books.

\section{CONTEXTUALIZING THE ISSUE}

\section{A. Global Scenario}

“Avian influenza, or 'bird flu,' is a contagious virus that normally infects only birds but occasionally crosses the species barrier to infect humans.” ${ }^{6}$ In 1997 a particular strain of avian influenza, the H5N1 virus, infected 18 people in Hong Kong, killing 6 of them. ${ }^{7}$ In October 2005, the laboratory investigations confirmed the presence of avian influenza in human beings from Vietnam, Thailand, Cambodia, China, Laos, and Indonesia. The migratory birds had spread the virus to Kazakistan, Turkey, and Romania. Of all these countries, Vietnam, China, and Thailand were most severely affected. "Since mid-2003, more than 100 human H5N1 cases have been diagnosed in Southeast Asia, causing more than 50 deaths." ${ }^{8}$ According to the WHO, "[o]f the few avian influenza viruses that have crossed the species barrier to infect humans, [the] H5N1 [virus] has caused the largest number of cases of severe disease and death in humans." ${ }^{9}$ The H5N1 virus is particularly alarming because if it mutates into a form that easily infects many humans, it has the potential to cause a deadly "pandemic", ${ }^{10}$ or a global disease outbreak in humans.

$6 \quad$ Brian T. Yeh, Influenza Antiviral Drugs and Patent Law Issues, CRS Rep. for Congress, RL33159 (2005), available at http://www.ipmall.info/hosted_resources/crs/RL33159_051118.pdf (last visited Jan. 29, 2008).

U.S. Department of Health \& Human Services, Avian InfluenZa (Bird Flu), http://www.pandemicflu.gov/general/avian.html (last visited Jan. 25, 2008).

Yeh, supra note 6.

World Health Organization, Avian Influenza Frequently Asked Questions, WoRLD HEALTH ORGANiZATION, Dec. 5, 2005, http://www.who.int/csr/disease/avian_influenza/avian_faqs/en/index.html\#present. when a new influenza A virus emerges for which there is little or no immunity in the human population, begins to cause serious illness and then spreads easily person-to-person worldwide”) (last visited Jan. 23, 2008). 


\section{B. Indian Scenario}

Prior to October of 2005, no case of H5N1 was reported either in birds or humans. The first incidence of avian flu in India was reported among poultry in the Navapur District of Maharashtra in February 2006. Subsequently, the Nandurbar District and Uchchhal Taluka, the Surat District of Mahrashtra and Gujarat, respectively, were also found to be infected with avian influenza. "In 2006, the poultry industry suffered an estimated loss of Rs 30,000 million, while in 2007 it was Rs 6,700 million." ${ }^{11}$ In July 2007, it resurfaced in Manipur. ${ }^{12}$ On January 11, 2008, it was once again reported in West Bengal when poultry farms in two districts, Dakshin Dinajpur and Birbhum, witnessed unusual mortality of birds. ${ }^{13}$ Despite a comparatively small number of human cases reported in neighboring countries, and not even a single case in India so far, the situation has been a prominent public health concern that warrants careful monitoring. Complacency is not an option becuase the situation could change very quickly, as the "[i]nfluenza viruses are genetically unstable and their behaviour cannot be predicted." ${ }^{14}$ Past experience has demonstrated that "H5N1 strain could infect humans directly without prior adaptation in a mammalian host.”15

\section{Availability of Antiviral Drugs Effective in Treating Avian Influenza}

Oseltamivir phosphate, marketed under the brand name Tamiflu, is an antiviral drug manufactured by the Swiss pharmaceutical company Roche, Inc. Tamiflu is not a vaccine, but is perhaps the most effective antiviral treatment for influenza. ${ }^{16}$ "The drug eases flu symptoms by preventing the influenza virus from spreading inside the human body." ${ }^{17}$ Some

11 Ashok B. Sharma, Avian Flu Appears Again in India, THE FINANCIAL EXPRESS, Jan. 15, 2008, available at http://www.financialexpress.com/news/Avian-flu-appears-again-in-India/261710/.

12

Id.

13

Id.

14

World Health Organization, Regional Office for the Western Pacific, Avian Influenza, WoRLD HEALth ORGANIZATION, http://www.wpro.who.int/health_topics/avian_influenza/.

15 World Health Organization, Avian Influenza and Human Health, World Health Organization, Apr. 8, 2004, http://www.who.int/gb/ebwha/pdf_files/EB114/B114_6-en.pdf. administer compared to Tamiflu. While Relenza must be inhaled, Tamiflu is given orally in capsule form. 
research studies have shown that Tamiflu is effective against the H5N1 avian and human virus strains. ${ }^{18}$

As the exclusive manufacturer of Tamiflu, Roche has had difficulty meeting the strong demand for the patented drug. According to the company, manufacturing the drug is a complicated process involving ten main steps and taking from six to eight months to produce a capsule of Tamiflu, once all the raw materials have been sourced. ${ }^{19}$ The World Health Organization has estimated that at Roche's present manufacturing capacity, "it will take a decade to produce enough oseltamivir to treat $20 \%$ of the world's population.”20

The Tamiflu production shortage had prompted both international and domestic pressures on Roche to relax its patent monopoly and permit other companies to manufacture generic versions of the drug. ${ }^{21}$ Such action would likely help to increase supplies of the flu treatment to meet the backlog of orders, as well as make the drug more affordable. In 2005, Indian companies such as Cipla, Ranbaxy, and Hetero Drugs claimed to have successfully reproduced a generic version of Tamiflu in small quantities in laboratory conditions; Roche argued that it is much more difficult and time-consuming to mass produce the drug. ${ }^{22}$ One of the challenges of producing large quantities of Tamiflu was obtaining enough supplies of its key active ingredient, shikimic acid, extracted from the pods of a Chinese cooking spice called star anise. ${ }^{23}$ It was reported that there may not be enough star anise in China or elsewhere to produce Tamiflu on a massive scale. ${ }^{24}$ To address this supply shortage, Roche had begun experimenting with a fermentation process using genetically altered E. coli

18 Roche, Inc., Factsheet Tamiflu, at 2, http://www.roche.com/med_mbfstamiflu.pdf.

Interview with Dr. GL Telang, India Head, Roche Scientific Co., in India.

World Health Organization, Antiviral Drugs: Their Role During a Pandemic, WoRLD Health ORGANIZATION, 2005, http://www.who.int/csr/disease/avian_influenza/antivirals2005_11_3/en/index.html.

See Donald G. McNeil, Indian Company to Make Generic Version of Flu Drug Tamiflu, N.Y. TIMES, Oct. 14, 2005, available at http://www.nytimes.com/2005/10/14/health/14virus.html. 2005 , available at http://online.wsj.com/article/SB113098216326386983.html?mod=home_whats_news_us. Nov. 5, 2005, available at http://www.nytimes.com/2005/11/05/business/05tamiflu.html.
Andrew Pollack, Is Bird Flu Drug Really So Vexing? Debating the Difficulty of Tamiflu, N.Y. TIMES, Id. 
bacteria to make the shikimic acid. ${ }^{25}$ Some scientists were confident that the fermentation process will prove to be more effective in producing the acid than relying on star anise. ${ }^{26}$ It is reported in some circles that the key active ingredient can now be produced synthetically in laboratories but the author is not sure of this claim.

Due to the impending danger of the spread of bird flu, and Roche's inability to produce and supply an adequate quantity of Tamiflu, many generic drug firms approached Roche for a license to produce generic versions of Tamiflu. Roche has repeatedly refused to grant any such licenses. The company cited the complex, time-consuming, and potentially explosive drug manufacturing process as the reason for retaining its exclusive rights to produce Tamiflu: "No one can do it faster. Our assumption is that it would take a generic company about three years to gear up. Therefore, it does not make sense to out-license manufacturing.”27 This corporate position prompted criticism not only from domestic and international government leaders but also from United Nations Secretary-General Kofi Annan. He argued that intellectual property laws should not prevent developing countries from obtaining supplies of Tamiflu and similar antiviral influenza medication in emergency health situations. ${ }^{28}$ Under such pressure, Roche softened its stance and agreed to discuss sublicensing arrangements with countries and companies interested in producing generic versions of Tamiflu. However, Roche cautioned that sub-licenses will only be issued to third parties that can realistically produce substantial amounts of the medicine in accordance with appropriate quality specifications, and safety and regulatory guidelines.

\section{Why was Roche Keen for Sublicensing Agreements?}

If Tamiflu was subject to a compulsory license, Roche would still be entitled to receive three to five percent royalties. However, Roche would not be able to control the sale price of the drug, and a cheaper generic version would mean smaller royalty payments. Roche thus preferred an alternative to the use of compulsory licensing, which are sublicensing agreements voluntarily negotiated by the company with third-parties of

25 Sabin Russell, Manufacturers Crank out Tamiflu at a Fever Pitch: Drugmaker Roche Eases Grip on Patent to Speed Production, S.F. CHRON., Nov. 10, 2005, available at http://www.sfgate.com/cgibin/article.cgi?f=/c/a/2005/11/10/MNG9UFLO421.DTL.

Id.

Keith Bradsher, Pressure Rises on Producer of a Flu Drug, N.Y. TIMES, Oct. 11, 2005, available at http://www.nytimes.com/2005/10/11/business/11drug.html.

Id. 
its choosing. ${ }^{29}$ Roche had selected 8 drug manufacturers out of 150 interested companies, with which it plans to hold sublicensing discussions by the end of November 2005.

Sublicensing agreements are contracts that permit other companies to manufacture and market generic versions of Tamiflu, in exchange for the companies paying licensing fees to Roche and agreeing to certain conditions. For example, the agreements may restrict the sale of generic Tamiflu to emergency Government stockpiles, prevent reexports of the drug, and place a time limit on the sublicense. An advantage of a sublicensing scheme is that generic companies can seek and obtain Roche's manufacturing expertise to ensure quality production. In addition, sublicensing allowed for coordination of obtaining the active ingredient in the antiviral drug, shikimic acid. However, some critics have asserted that these voluntary sublicensing agreements might only help rich countries to stockpile Tamiflu, and do little to improve the treatment's availability for poorer countries. They maintain that under such agreements, Roche would likely still retain the right to control pricing and could reap large profits on generic Tamiflu. $^{30}$

\section{TAMIFLU'S PATENT DISPUTE AND ITS STATUS IN INDIA}

Gilead Sciences, Inc, a California biotech company, invented Tamiflu in 1996. Subsequently, Gilead licensed all its commercial and manufacturing rights to Roche in exchange for a $\$ 50$ million license fee ${ }^{31}$ and royalty payments during the term of the drug's patent. Tamiflu is patent protected until 2016. ${ }^{32}$ In June 2005, Gilead notified Roche that it was terminating the 1996 license agreement pursuant to a clause that provides for contract cancellation due to a "material breach" of its terms. ${ }^{33}$ Gilead claimed that Roche for many years had failed to use "best efforts" to manufacture and promote the drug, and was \$18

Factsheet Tamiflu, supra note 17 (stating that Roche is willing to "negotiate with any partner about granting a license [for Tamiflu] at equitable conditions" and considers "criteria [such as] quality, technical ability, capacity and the speed of bringing that capacity on stream”).

Brook K. Baker, Roche's Secret, Sub-Licenses for Tamiflu Will Not Bring Poor People in From the Cold, HEALTH Now, Oct. 31, 2005, http://www.health-now.org/site/article.php?articleId=504\&menuId=1.

See Sabin Russell, Biotech Firm Wants to Regain Control of Avian Flu Drug; Gilead Says Deal with Roche Inc. Threatens Tamiflu's Production, S.F. CHRON., June 24, 2005, available at http://www.sfgate.com/cgi-bin/article.cgi?file=/c/a/2005/06/24/MNGHTDE8LG1.DTL.

Factsheet Tamiflu, supra note 17, at 1. 
million behind in royalty payments. ${ }^{34}$ However, after the arbitration, on November 16, 2005, the companies announced that they had reached an amicable settlement and that they would establish joint committees to oversee the coordination of global manufacturing and commercialization, issuing third-party licenses to generic drug makers, and pandemic planning. ${ }^{35}$

Tamiflu is not a patented drug in India. Roche and Gilead Sciences have filed 7 patents in India. ${ }^{36}$ Of these seven, two are mail box ${ }^{37}$ applications - both filed by Gilead in 1996. One of them very broadly claimed compositions comprising Oseltamivir or its salts. The claim of the other application is equally broad, except for the limitation that they claim only enteric coated compositions. The Indian pharmaceutical firms contend that if these patents were indeed granted with the same or similar broad claims, then all other manufacturers in India would need to get either voluntary licenses from Roche/Gilead or compulsory licenses from the Indian Government. ${ }^{38}$ One process patent for preparing an enteric-coated composition (formulation) of several oseltamivir analogues has been filed, and four process patent applications have been filed by Roche claiming various processes for preparing Oseltamivir intermediates from different starting materials. ${ }^{39}$

The Indian Patent Office has granted two process patents for Oseltamivir Phosphate, but it is not a patented drug in India. ${ }^{40}$ Other applications are pending examinations and

$34 \quad I d$

Press Release, Roche, Inc., Roche and Gilead End Dispute on Influenza Drug Tamiflu (Nov. 16, 2005), available at http://www.roche.com/med-cor-2005-11-16.

Indian Patent Office database, available at http://www.patentoffice.nic.in/.

Id. As per the requirement of the TRIPS Agreement, the Indian Patent Act was amended in 1999 to provide that applications claiming pharmaceutical inventions would be accepted and kept in a mailbox, to be examined in post January 1, 2005 - the deadline for become fully TRIPS compliant. The Patent (Amendment) Act, No. 17 of 1999; India Code (1999), available at http://ipindia.nic.in/ipr/patent/patact_99.pdf Laboratories Ltd., in India.

See Basheer, supra note 4. IN 190983 (Application No. 2791/DEL/1998) titled 'Novel Compounds and Methods for Synthesis and Therapy' in the name of Gilead claims a process of making enteric coated Oseltamivir capsules. IN 192890 (Application No. 153/MAS/01) titled 'Tamiflu Via Deils Alder' in the name of Hoffman-La Roche claims a Diels-Alder process using furan as the raw material. Other patent applications claiming processes for making Oseltamivir have been filed by Roche (but not granted as yet): Application No. 305/MAS/2001 titled ‘Tamiflu Gallocarboxylic Acid Approach’; Application 
clearance that would most probably not occur before 2009 because it takes on average four years for an application to mature to a patent in India. ${ }^{41}$ It will take not less than one and a half years even if they were processed on fast track basis. Thus, since no product patent is granted to Roche, the process patents would not cause any hindrance to the Indian pharmaceutical industry to manufacture Tamiflu because they can produce Tamiflu by alternative processes without infringing the processes patented by Roche.

\section{EXPLORING THE FLEXIBILITIES}

Although the mailbox applications are pending examinations and they may mature as patents, the critical issue is what options are available to India to address the immediate threat of avian influenza, and also to deal with such situations in future. This section will explain various legal provisions of the Patent Act that can be exploited by the government and the Indian pharmaceutical industry.

\section{A. Pre-Patent Options}

\section{Challenge the Mailbox Application by Filing a Pre-grant Opposition}

One obvious choice for the Indian firms is to challenge the mailbox applications filed by Gilead for the product so that it does not fructify into a patent. Section 25 of the Act provides for pre-grant opposition for pending patent applications. The pre-grant opposition may be filed virtually on all grounds of 'patentability criteria' specified under the Patent Act. ${ }^{42}$ The Act has also expanded the opportunities for filing a pre-grant opposition, as "any person” can now file one. ${ }^{43}$ Basheer has suggested some grounds for filing a pre-grant opposition in the instant case. ${ }^{44}$

443/MAS/2000 titled 'Process for Preparing Neuraminidase Inhibitor'; and Application No. 1037/MAS/2000 titled 'Phosphine Reduction of Azides to Amides'.

$41 \quad$ See Shamnad Basheer \& Tahir Amin, Taming of the Flu: Working Through the Tamiflu Patents in India, 11.2 J. OF INTELL. PROP. RTS. 113, 121 (2006).

See The Patent (Amendment) Act § 25(1), No. 15 of 2005; India Code (2005). The prerequisites for patentability are non-obviousness (or "inventive step”) and utility (or industrial applicability) and new invention (or new-invention). Id. 
Leading Indian generic manufacturer Cipla filed a pre-grant opposition against the Roche/Gilead Oseltamivir product patent application in April 2006 on the grounds of “"known prior-art, invalid claim, lack of novelty and inventive step.",45 "Prior-art is when knowledge on the drug already exists before the cut-off date - of 1995, in this case - and, hence, a patent cannot be claimed." ${ }^{46}$ Another company, Meditab Specialities, has also filed a pre-grant opposition on Oseltamivir. ${ }^{47}$

This provision of the Act is being very effectively utilized not only by Indian generic companies but also by non-governmental organizations and healthcare advocacy groups as a new and potent weapon to challenge the grant of patents on essential medicines. ${ }^{48}$ Although most of the newly filed pre-grant oppositions are still pending, some have already succeeded in preventing the grant of Indian patents. ${ }^{49}$

\section{Prior User Rights vis-à-vis Patents from Mailbox Applications}

The Act introduced a new proviso in Section 11A:

On and from the date of publication of the application for patent and until the date of grant of a patent in respect of such application, the applicant

45 P.T. Jyothi Datta, Cipla Opposes Patent Application on Bird-Flu Drug, ThE Hindu Business Line, May 1, 2006, available at http:/www.thehindubusinessline.com/2006/05/02/stories/2006050202250500.htm.

47 Network of People Living with HIV/AIDS, the Manipur Network of Positive People, and the Lawyers' Collective HIV/AIDS Unit in the Kolkata branch of the Indian Patent Office against the grant of a patent on Glaxo’s combination therapy sold under the brand name ‘combivir' for HIV/AIDS)

49

For example, Indian cancer patients (along with generic drug manufacturers) filed a pre-grant opposition against the grant of a patent on Novartis' claimed beta-crystalline form of imatinib mesylate, the active ingredient in an anti-cancer drug sold by Swiss pharmaceutical manufacturer Novartis AG under the brand name Gleevec . the pre-grant opposition was filed under Section 3(d) of the Act claiming that Gleevec was "a new form of an old drug”. See 41 OfFICIAL JOURNAL OF THE PATENT OfFICE 23859, 24057, 2005, available at

http://ipindia.nic.in/ipr/patent/journal_archieve/pat_arch_102005/official_journal_28102005.pdf (for the relevant Patent Application No. 1602/MAS/1998A filed by Novartis AG for the active ingredient in Gleevec). The Indian Patent Office refused allowing the Gleevec application. See Notice for Termination of Exclusive Marketing Right EMR/1/2002,7 OfFICIAL JOURNAL OF THE PATENT OfFICE 4400, 2006, available at

http://patentoffice.nic.in/ipr/patent/journal_archieve/journal_2006/pat_arch_022006/official_journal_17022 006.pdf (confirming that "the Patent application 1602/Mas/98 was refused by the Controller as a result of pre-grant opposition”). The Controller’s refusal of Novartis’s patent application also had the effect of extinguishing its EMR, which had been the subject of ongoing litigation in the High Courts. 
shall have the like privileges and rights as if a patent for the invention had been granted on the date of publication of the application:

Provided that the applicant shall not be entitled to institute any proceedings for infringement until the patent has been granted: Provided further that the rights of a patentee in respect of [mailbox] applications made under sub-section (2) of section 5 before the 1st day of January, 2005 shall accrue from the date of grant of the patent:

Provided also that after a patent is granted in respect of [mailbox] applications made under sub-section (2) of section 5, the patent-holder shall only be entitled to receive reasonable royalty from such enterprises which have made significant investment and were producing and marketing the concerned product prior to the $1^{\text {st }}$ day of January, 2005 and which continue to manufacture the product covered by the patent on the date of grant of the patent and no infringement proceedings shall be instituted against such enterprises. $^{50}$

This newly added proviso to Section 11A of the Act considerably dilutes the monopoly granted to pharmaceutical patents arising out of mailbox applications. It prohibits infringement lawsuits specific to patents that are issued after January 1, 2005 from mailbox applications, if a competing firm has made "significant investment" and was already "producing and marketing” (presumably in India) the patented product prior to January 1, 2005. ${ }^{51}$ Owners of the effected patents are entitled to recover only "reasonable royalties" for ongoing infringement; injunctive relief and infringement lawsuits are precluded. ${ }^{52}$ This provision combines features of both the "prior user right[s]" defense and "compulsory licensing." 53 The distinction, however, is that a 'prior user right' is generally implemented as a complete defense to infringement, disallowing recovery of any damages by the patentee from the prior user. According to the provision under Section 11A(7), though, the patentee is entitled to recovery of "reasonable royalty" even if the competitor had not obtained any governmental (or patentee) approval before undertaking its manufacturing of the nowpatented drug.

50 The Patent (Amendment) Act §11A(7), No. 15 of 2005; India Code (2005) (emphasis added).

51

Id. Although the statute does not state a geographic limitation, presumably the prior user defense of Section $11 \mathrm{~A}(7)$ is limited to those enterprises who manufactured the patented drug in India prior to January 1, 2005 and who continue to do so after January 1, 2005.

$52 \quad$ Id

53

Frederick M. Abbott, Beginning of a New Policy Chapter, The FinANCIAL ExPRESS, April 6, 2006, available at http://www.financialexpress.com/print.php?content_id=87112. Professor Abbott has referred to the $\S 11 \mathrm{~A}(7)$ remedies limitation as “a form of 'prior user right' adapted to India's unique situation.” Id. 
The Indian firms cannot take advantage of this provision because none of them had made 'significant investment' and were 'producing and marketing' Tamiflu prior to 2005. Basheer, however, asserts that the Indian firms can in fact utilize this flexibility and can manufacture Tamiflu undeterred until a patent is actually issued; he argues this is because the Act provides that such retrospective rights under Section 11A do not apply to pharmaceutical mailbox applications. ${ }^{54}$ The author is, however, doubtful that the Act provides such special treatment to pharmaceutical mailbox applications. ${ }^{55}$

This provision of India's new patent regime is a constant source of tension between the MNCs and Indian generic firms. The MNCs argue that Section 11A(7) remedies not only abrogates the patents arising out of mailbox applications, but also that it imposes serious limitations on patent owner remedies. Hence, it takes away the very sanctity of mailbox and transitional protection as envisaged in the TRIPS Agreement, ${ }^{56}$ and, therefore, "definitely makes the provision TRIPS non-compliant." ${ }^{\text {57 }}$ The Organization of Pharmaceutical Producers of India (OPPI) argues that contrary to the requirement of TRIPS Article $27.1^{58}$, Section 11A is discriminatory based on the "field of technology", i.e. the field of pharmaceutical products. ${ }^{59}$ In addition, India's remedies limitation for mailbox patents severely restricts the exclusive rights provided under TRIPS Article 28.1(a) by limiting the patentee to "reasonable" royalties. ${ }^{60}$ The other point of discontentment is the mechanism of seeking the limited relief under the new remedies limitation on mailbox patents; in the absence of a

$54 \quad$ Shamnad Basheer, India's Tryst with TRIPS: The Patents (Amendment) Act 2005, 1 INDIAN J.L. \& TECH. 15 (2005). discrimination as to
locally produced").

TRIPS, supra note 56, at art. 28.1(a) (requiring that where the subject matter of a patent is a product, the patent owner shall have the exclusive rights to prevent third parties not having the owner's consent from the acts of: making, using, offering for sale, selling, or importing for these purposes that product. ... )

TRIPS, supra note 5, at art. 28.1(a) (mandating that the patent owner shall have the exclusive rights "to prevent third parties not having the owner's consent from the acts of: making, using, offering for sale, selling, or importing for these purposes that product”). 
patent infringement lawsuit, the statute does not specify how owners of patents issuing from mailbox applications are to establish their claim for "reasonable" royalties, let alone how the amount of such royalties will be determined. ${ }^{61}$

On the other hand, the indigenous firms see this provision as critical to the protection of their industry and a legitimate interpretation and exploitation of the flexibilities provided to India by the TRIPS Agreement's transition period arrangements. ${ }^{62}$ Though this controversial remedies limitation has not yet been tested, it certainly has the potential to catalyze the filing of another dispute proceeding against India in the WTO. ${ }^{63}$

\section{B. Post Patent Options}

While no mail box applications filed by Gilead/Roche have yet matured into patents, if any of them does, the following legal options are available to the Indian firms for production of Tamiflu.

\section{Voluntary Licenses}

An Indian generic manufacturing firm could approach Roche and obtain a voluntary license. During the crisis of 2005, two Indian generic pharmaceutical companies, Cipla and Ranbaxy, approached Roche to work out a voluntary licensing deal, but it didn't materialize. Hetero Drugs, a Hyderabad based firm secured a sub-license from Roche to manufacture and market both the Active Pharmaceutical Ingredient (API) and the finished product of Oseltamivir for supply to India, least developed countries, and developing countries. ${ }^{64}$

61 Though the Act stipulates that the generic manufacturers would have to pay a "reasonable royalty" to the patent holder, it does not define the term "reasonable.” Love asserts that "soon a large number of compulsory licenses will be issued for products now manufactured in India, which are subject to the mailbox patents. This will increase the familiarity with compulsory licensing and provide needed expertise in setting reasonable remuneration to patent owners.” See James Love, Options to Traditional Patents, THE FINANCIAL EXPRESS, Apr. 6, 2005, available at http://www.financialexpress.com/print.php?content_id=87107. Ideally, the royalty rate should have been fixed at $4 \%$, following the practice adopted by Canada for many years, or at $5 \%$ following South Africa. See Prabhu Ram, India's New “TRIPS-Compliant” Patent Regime-Between Drug Patents and the Right to Health, 5 CHI-KENT J. INTELL. PROP. 195 (2006).

Interview with Amar Lulla, Joint MD, Cipla, in India; interview with NH Israni, Bluecross Laboratories Ltd., in India.

63 in India.

Interview with Sree Patel, GlaxoSmithKline, in India; interview with Lobo Yolynd, Pfizer (India) Ltd.,

64

See Roche Grants Tamiflu License to Hetero Drugs, Times OF InDIA, Dec. 24, 2005, available at http://timesofindia.indiatimes.com/articleshow/1344422.cms. 
During the said crisis Hetero approached the government claiming that it was in a position to supply 100,000 capsules before December 12, 2005, another million capsules by January 31, 2006, and from February 2006 onwards the company would be in a position to meet the expected demand of the Indian. Cipla and Ranbaxy also informed the government that they were in position to manufacture and supply generic versions of Tamiflu. ${ }^{65}$

It may, however, be noted that voluntary license agreements result in increased prices of the drugs because the generic manufacturers have to pay licensing fees and/or royalties, which are factored into the selling price of the drug. ${ }^{66}$ In any event, such high royalties are unwarranted in the Indian context because transfer of technology is not required; the Indian generic manufacturers are able to produce the generic version of the patented drug through "reverse-engineering” processes. ${ }^{67}$ Furthermore, working out a voluntary license agreement between a generic manufacturer and a brand name company is a relatively rare occurrence and is often difficult to negotiate, with the brand name company placing limits on production capacity, demanding high royalty fees, or imposing other similar restrictions. ${ }^{68}$

\section{Compulsory Licenses}

\section{a. Section 84}

If an attempt to obtain a voluntary license fails, any generic manufacturer could invoke the provisions of Section 84 of the Act by filing an application for a compulsory license on any of the following three grounds:

(1) the 'reasonable requirements' of the public with respect to the patented invention have not been satisfied;

(2) the patented invention is unavailable to the public at a 'reasonably affordable price';

or

(3) the patented invention is not 'worked' in the territory of India.

65 Interview with Paresh Johri, Deputy Secretary, Department of Chemicals and Petrochemicals, Government of India of the deal but market sources say that the royalty was fixed somewhere between 10 to $15 \%$. 


\section{Ground One - Section 84(1)(a) "Reasonable Requirements" of the Public}

The first ground on which a Section 84 compulsory license may be sought is when "reasonable requirements of the public with respect to the patented invention have not been satisfied.” The generic firm interested in getting a license under this provision will have to show that Roche and Hetero are unable to produce enough drugs to meet the requirements of public.

Both the MNCs and the Indian generic manufacturers do not seem to be satisfied with this provision. While on one hand, the MNCs claim that the statutory scheme gives the Controller virtually unfettered discretion in determining whether this criterion has been satisfied, ${ }^{69}$ on the other hand, the Indian generic manufacturers feel that this clause is sloppily drafted as it leaves lot of room for interpretation. ${ }^{70}$ The MNCs also say that not only this clause sloppily drafted, but more importantly given the breadth of its wording, virtually any refusal of a patentee to license could be deemed prejudicial to some form of trade in India. ${ }^{71}$ Moreover, they feel that this ground can even be satisfied not only when a domestic industry is harmed by a patentee's refusal to license, but also when that refusal means that "a market for export of the patented article manufactured in India is not being supplied or developed." 72 The MNCs further contend that this provision is contrary to the TRIPS Agreement as reference to supplying export markets remains in the general-purpose Section 84 Avenue of compulsory licensing and is not confined to the new Section 92A procedure. The Government of India has endeavored to address this issue through amendment of Section 90 of the Act, by providing that the Controller "shall endeavor to secure" that a compulsory license "is granted with a predominant purpose of supply in the Indian market and that the licensee may also export the patented product, if need be in accordance with the provisions of

69 Dr. GL Telang, Saumil Mody, Roche Scientific Company (India) Pvt. Ltd.; Sree Patel, GlaxoSmithKline They were of the opinion that statute provides that this criterion has not been satisfied if any of a host of various circumstances listed in the section is not fulfilled. See § 84(7)(a)-(e), Patent (Amendments) Act, (2005). Drugs

Amar Lulla, Cipla; Dr. Vijayaraghavan, Ranbaxy; M. Sirinivas Reddy, Director Marketing, Hetero

See supra note 69. 
sub-clause (iii) of clause (a) of sub-section (7) of section 84;"” however, the true test will come when the provision is implemented. ${ }^{73}$

\section{Ground 2 - Section 84(1)(b) Unavailability at a Reasonable Price}

The second ground on which a compulsory patent license can be sought under Section 84 is that "the patented invention is not available to the public at a reasonably affordable price.”

Since the statute provides no guidance as to how the Controller is to determine what a “reasonably affordable price” is, the license seeker under Section 84(1)(b) must make out a prima facie case. ${ }^{74}$ The patent owner would have an opportunity to counter the compulsory license applicant's evidence with the patentee's own evidence by initiating an opposition procedure.

In the instant case, it may be difficult to invoke this provision for obtaining CL on this ground. Hetero is currently selling Tamiflu at Rs. 75/- per tablet to the government and since Cipla is selling the generic equivalent of the same at Rs. 65/-, so it may be difficult to establish that the Hetero's drug is unaffordable. ${ }^{75}$

\section{Ground 3 - Section 84(1)(c) Failure to Work the Patent}

The third ground on which a Section 84 compulsory license may be issued is that the "patented invention is not worked in the territory of India."

Although in the instant case this ground cannot be invoked because no patent has been granted on Tamiflu in India, this provision has raised the maximum ire of foreign patentees. The MNCs contend that if the word "worked" is not interpreted broadly enough to encompass imports, then the patented pharmaceutical products that are manufactured outside of India but imported into India for sale could also be subjected to compulsory license under Section 84(1)(c), and is in contravention to the 'non-discrimination' provision of Article 27.1 of the

\footnotetext{
73 Interviews with Dr. GL Telang, Saumil Mody, Roche Scientific Company (India) Pvt. Ltd.; Sree Patel, GlaxoSmithKline; Lobo Yolynd, Pfizer (India) Ltd. 
TRIPS Agreement. ${ }^{76}$ India, like several other advanced developing countries, has retained domestic working requirements to protect and create incentives for indigenous industry. The domestic working requirement is a pervasive theme of India's patent laws and is evidenced in the Act by Section 83's statement of "general principles," which provides that Indian patents are not granted merely to enable patentees to enjoy a monopoly for the importation of the patented article. ${ }^{77}$ Mueller asserts that this controversial provision which retains working requirements as a tool for domestic economic enhancement will undoubtedly be challenged by those MNCs which strongly prefer to consolidate production facilities in order to achieve economies of scale and related efficiencies. ${ }^{78}$

Since there is no definitive WTO ruling ${ }^{79}$ existing on the apparent conflict between retention of local working requirements as a compulsory licensing trigger and the nondiscrimination provision of TRIPS Art. 27.1., this unresolved conflict may be re-ignited by India's new pharmaceutical product patents regime and the susceptibility of foreign-owned product patents to compulsory licensing. ${ }^{80}$

It may, however, be noted that the provisions under Section 84 can be invoked only after the expiry of three years after the grant of the patent. Hence, compulsory license cannot be issued for production of Tamiflu under this provision.

\section{b. Compulsory License U/s 92: Notification by Government}

The second way of obtaining a compulsory license is under Section 92 of the Act. This is the government's primary mechanism under the new patent regime for ensuring that

76

.
to the AIDS Crisis in Developing Countries, available at http://ssrn.com/abstract=794228. Brazil's inclusion of a failure-to-domestically-work trigger for compulsory patent licensing caused the US to initiate a dispute proceeding in the WTO. On May 30, 2000 the US requested consultations with Brazil concerning "those provisions of Brazil's 1996 industrial property law (Law No. 9,279 of 14 May 1996; effective May 1997) and other related measures, which establish a 'local working' requirement for the enjoyability of exclusive patent rights.” World Trade Organization, Annual Report 2002, at 108, available at http://www.wto.org/english/res_e/booksp_e/anrep_e/anrep02_e.pdf. The US government challenged the said law under WTO's Dispute Settlement mechanism in 2002. A WTO panel never resolved the dispute, however, because the U.S. dropped its claim, most likely in response to public pressure. 
in cases of national emergency, extreme health urgency, etc., the Indian public has access to patented medicines. Section 92 provides for the filing of compulsory license applications at any time after the Government of India has declared by notification in the Patent Office's Official Journal that it is necessary to make compulsory licenses available under a particular patent (or patents) "in circumstances of national emergency or . . . extreme urgency or in case of public non-commercial use." 81

Subsequent to such a declaration, any private firm or a public-sector firm can apply for a license. In contrast with Section 84 licenses, ${ }^{82}$ Section 92 licenses are broadly available for all medicines, without any prior negotiation with patent owners. According to scheme of things under Section 92, following the requisite government notification, the Controller shall grant the applicant a license under the patent on such terms and conditions that would make available the drugs manufactured under the patent to the public at the lowest prices consistent with the patentees deriving a reasonable advantage from their patent rights. ${ }^{83}$ There are not many procedural protections for patentees under Section 92 of the Act. The patentee does not have the opportunity to oppose the grant of a compulsory license under this section. ${ }^{84}$

The government can resort to this provision to foster stockpiling of Oseltamivir in the event of avian flu pandemic. However, whether the government would invoke this provision is a million dollar question and it depends upon the political will of the government.

\section{c. Compulsory License U/s 92A: Exports for Public Health}

Section 92A of the Act creates a new avenue for compulsory licensing that will permit manufacturing and exporting of patented 'pharmaceutical products' from India to other countries having insufficient or no manufacturing capacity. ${ }^{85}$ This section essentially

$81 \quad$ See Patent (Amendments) Act, § 92(3) (2005).

See Patent (Amendments) Act, § 84(6)(iv) (2005) (stipulating that in considering a compulsory license application filed under Section 84, the Controller shall take into account whether the applicant has made efforts to obtain a license from the patentee on reasonable terms and conditions and such efforts have not been successful within a 'reasonable period' of time. For the purposes of clause (iv), a 'reasonable period' shall be construed as “a period not ordinarily exceeding a period of six months.”). available for manufacture and export of patented pharmaceutical products to any country having insufficient or no manufacturing capacity in the pharmaceutical sector for the concerned product to address public health problems, provided that a compulsory license has been granted by such country or such 
incorporates the flexibilities granted in the August 30 Decision. The Act defines the relevant 'pharmaceutical products' as "any patented product, or product manufactured through a patented process, of the pharmaceutical sector needed to address public health problems and shall be inclusive of ingredients necessary for their manufacture and diagnostic kits required for their use.”86 An application for a compulsory license under Section 92A can be filed at any time after a patent has been issued. Unlike Section 84, the Act does not provide for any procedural mechanisms allowing the patent owner to oppose the grant of a compulsory license under Section 92A

The MNCs are extremely critical of wording of Section 92A. The debate is whether the compulsory license framework provided under Section 92A is compliant with the analogous TRIPS provisions. Mueller argues that India's implementation goes beyond what has been provided for in the August 30 Decision. She notes that

India does not require as a prerequisite for issuing a Section 92A compulsory license that the importing country have already granted (or intends to grant in the future) its own compulsory license to permit the import of the patented pharmaceuticals in the importing country (assuming that a patent covering the imported product is in force there). It is enough if the importing country has, by notification or otherwise, allowed importation of the patented pharmaceutical products from India. ${ }^{87}$

The MNCs also allege that in contrast with anti-diversionary provisions of the August 30 Decision, India's Section 92A is completely silent on any obligation of the Indian government or the compulsory licensee to specify the amount of pharmaceutical products that will be exported, to specially label or mark those products, or to make public any information about the export. ${ }^{88}$ On the contrary, the Indian generic manufacturers argue that the fears of the MNCs are unfounded because the Controller has wide discretion to set the terms and conditions of a Section 92A compulsory license and the Controller could, in each individual case, set a quantity limit on the amount of pharmaceutical product to be made and exported,

country has, by notification or otherwise, allowed importation of the patented pharmaceutical products from India. Id.

See Mueller, supra note 3. 
require the licensee to specially package or mark its products, or impose other limits and obligations. $^{89}$

There are not currently many serious issues with respect to this provision. In the long run, it is expected that as with other open questions concerning India's new patent law, the TRIPS compliance issue may turn on the manner in which India actually implements its Section 92A framework. Widespread use of the Section 92A for compulsory license to export patented medicines appears likely. ${ }^{90}$ There are currently fifty countries recognized by the WTO and the United Nations as least-developed countries, ${ }^{91}$ so the available export market for Indian generic companies is potentially very significant. But whether the Indian generic manufacturers would utilize this flexibility is a question of economic viability that is discussed later in the paper.

\section{Parallel Imports}

Another important flexibility that can be exploited is the provision of parallel imports. The Act adopts the principle of "international exhaustion of patent rights." 92 The Act goes even further, by shielding importation of products acquired from sources other than the patentee in countries not yet recognizing product patent protection. Section 107A(b) of the Act provides that:

Importation of patented products by any person from a person, who is duly authorized under the law to produce and sell or distribute the product, shall not be considered as a infringement of patent rights. ${ }^{93}$

Interview with Amar Lulla, Joint MD of leading generic company Cipla takes the position that even in situations where it will now be prevented by the new product patent regime from copying and selling patented medicines within India, it would nevertheless be able to make those products for export to leastdeveloped countries and to any other countries that have the legal right to import those products.

As of August 2006, the WTO recognized 50 member countries as least developed countries in accordance with the United Nations' designation. See World Trade Organization, Least-Developed Countries, available at http://www.wto.org/english/thewto_e/whatis_e/tif_e/org7_e.htm.

Parallel imports occur when patented medicines produced or sold abroad with the consent of the patent owner are subsequently imported into the domestic market at cheaper prices without the consent of the owner. See Agreement on Trade-Related Aspects of Intellectual Property Rights, Apr. 15, 1994, Marrakesh Agreement Establishing the World Trade Organization, Annex 1C, Legal Instruments - Results of the Uruguay Round, 33 I.L.M. 81 (1994) (stating that the right to prevent third parties not having the owner's consent from importing a product is subject to the provisions of Article 6 on exhaustion), available at http://www.wto.org/english/tratop_e/trips_e/t_agm2_e.htm. 
It has been suggested that Indian generic firms could capitalize on the breadth of this provision "by shifting their manufacturing base to neighboring LDCs such as Bangladesh (which have time till 2015 to shift to a pharmaceutical product patents regime) and importing the same into India.” Such a strategy is not far-fetched. In fact, generic pharmaceutical production is already well established in Bangladesh. For example, Beximco, the leading generic drug manufacturer in Bangladesh, has already launched production of "Oseflu," its version of the bird flu anti-viral Tamiflu, which is the subject of pending patent applications in India that are assigned to Hoffman-La Roche. ${ }^{94}$

Although most developed country patent regimes have refused to adopt the notion of international exhaustion of patent rights, the developing and least developed world strongly favor the concept as a means of ensuring access for its citizens to lower-cost drugs.

MNCs contend that if called upon to defend the legitimacy of its broad Section 107A(b) shield from infringement, India may need to rely on more than simply the silence of TRIPS. The dispute will turn on the scope and meaning of "exhaustion." Basheer has suggested that India's Section 107A(b) provision violates TRIPS by “going even beyond 'exhaustion. ${ }^{95}$ While it may be difficult for India to justify the new provision, it may counter that it is merely exploiting the flexibilities provided under TRIPS Agreement, particularly in view of the Doha Ministerial's Declaration on the TRIPS Agreement and Public Health that "the effect of the provisions in the TRIPS Agreement that are relevant to the exhaustion of intellectual property rights is to leave each member free to establish its own regime for such exhaustion without challenge, subject to the MFN and national treatment provisions of Articles 3 and 4."96

\section{Government Use}

Basheer \& Tahir assert that apart from the compulsory licensing provisions discussed above, one can exploit the flexibilities provided U/s 99 to 103 (Chapter XVII - 'Use of

\footnotetext{
$94 \quad$ See Mueller, supra note 3.

95 See Basheer, supra note 54. Since there is no requirement that the patentee have sold the good in the country from where it is exported, the provision virtually extinguishes the exclusive right to import. See id. 
Inventions for Purposes of Government') and Section 47 of the Act ('Government use of inventions') without running the risk of being sued for infringement. ${ }^{97}$

No doubt, the provisions under Chapter XII and Section 47 are wide in scope and can be invoked to help manufacture Oseltamivir for use in government hospitals and other entities that are related to the government.The real issue is whether India has a public health infrastructure in place to ensure that the drugs are supplied to all the infected through the government machinery, or whether supply of drug through private channels would also be construed as being for the “purpose of Government?” Since the TRIPS Agreement is silent on these subtle issues, perhaps the best answer is to interpret these provisions to address the public health needs and run the risk of litigation. Once again, this leads to the question of political will of the government that is discussed later in this paper.

\section{ADMINISTRATIVE FEASIBILITY AND ECONOMIC VIABILITY}

The discussions in the preceding sections highlight various legal options that could be strategically employed by the Indian government and the Indian generic firms to aid the continued manufacturing of affordable generics in the post-TRIPS era. However, mere existence of this legal framework does not ensure that the Indian firms will necessarily be able to effectively use it. They will exploit these flexibilities only if they are procedurally simple to administer and are economically viable. Indian firms and patent law experts have expressed reservations about the efficacy of these provisions due to procedural constraints and economic viability.

\section{A. Procedural Constraints}

The Act broadly allows for compulsory licensing in two circumstances; supply of patented drugs and medicines within the country itself (under Sections 84 and 92) and manufacture of drugs for export to poor countries having insufficient or no capacity to produce drugs (under Section 92A).

Though the compulsory licensing provision existed in the Patent Act of 1970, it was redundant in the pre-TRIPS era because the Indian firms could develop their own processes and produce the patented drugs. But in the product patent regime, it is crucial to have a simple,

$97 \quad$ See Basheer \& Tahir, supra note 41. 
transparent, and easy to administer compulsory licensing system, because otherwise the indigenous firms will not be able to produce a patented drug even if they develop the processes of manufacturing it. $^{98}$ Chaudhuri asserts that the amendments have been brought about mechanically and the government has adopted a stricter compulsory licensing regime than what is required under TRIPS. ${ }^{99}$ For instance, the wording of the grounds for granting compulsory licenses in Section 84 is not amenable to easy interpretation and the procedure specified is excessively cumbersome and legalistic. It also provides the patentees with opportunities to buy time through litigations. In addition, except for fixing the 'reasonable' time period of six months for negotiations between the generic company and the patent holder, the procedure is open-ended without any time limit imposed for the ultimate grant of compulsory licenses. Furthermore, the availability of injunctive relief in compulsory licensing litigation gives extra power to the patentee to block the compulsory license for a long period of time, and it may be years before a compulsory license is granted. ${ }^{100}$ The huge legal expenses involved in fighting the MNCs holding the patents may dissuade the generic companies from applying for licenses in the first place. ${ }^{101}$ As contemplated by the TRIPS Agreement, Section 84 sets up compulsory licensing as a remedy for anti-competitive behavior by patentees, but the details of anti-competitive practices are neither spelled out clearly in the Patent Act of 2005 nor in Competition Act of 2003. ${ }^{102}$ This leaves a gaping hole in the process that is likely to be exploited by the patent holder. Ultimately, clear and effective grounds for the issuance of a compulsory licence have not been provided in the legislation. For instance, it is unresolved whether a compulsory license can be issued when a patentee refuses to issue a voluntary license on 'reasonable commercial terms.' 103

98

See Commission on InTEllectual Property Rights, INTEgRATING INTELLECTUAL PROPERTy RightS AND DEVELOPMENT (2002), available at http://www.iprcommission.org/papers/pdfs/final_report/CIPRfullfinal.pdf.

See Sudip Chaudhuri, TRIPS and Changes in Pharmaceutical Patent Regime in India, 26 (Indian Institute of Management, Calcutta, Working Paper No. 535, 2005), (“Article 1 of TRIPS has made it clear, member countries are "not obliged to implement in their laws more extensive protection than is required by this Agreement ....'”). Manufacturers’ Association

Id. 
The Act also fails to remove the stipulation under the Patent Act of 1970 that allows applications for compulsory licenses only after three years have passed since the grant of the patent. Hence, in practice the request for a compulsory license cannot be considered for at least three years and six months from the date of the grant of the patent. ${ }^{104}$ The only exceptions are in the cases of a national emergency, public health urgency, or public noncommercial use. The Act also fails to provide the safeguard available within TRIPS Article 44, which effectively allows member States to limit remedies on the remuneration that would be available to the patent holder where third parties are authorized by the government, without the authorization of the right holder, to use the patented good. ${ }^{105}$ Since the procedure of granting compulsory licenses is besieged with uncertainty, it is likely that the indigenous firms may be hesitant to undertake investments to generate efficient processes. ${ }^{106}$

The compulsory licensing provision under Section 92A, which implements the August 30 Decision, appears to be one of the easiest ones to invoke. It is yet to be seen, however, whether the Indian generic manufacturers will be keen to exploit it. As of now, except for a few drugs such as anti-HIV/AIDS medications, the industry groups, pharmaceutical experts, and trade experts feel that the obligations under the August 30 Decision are practically "inoperative"107 and "un-implementable"108 and actually create a system that is "commercially unviable"109 for the indigenous industry. The obligations and procedures laid down in the August 30 Decision are fairly complex and cumbersome, which adds many constraints on the business practices of the generic manufacturers. Any problems or delays on the importing country end - with notification, establishment of insufficient capacity, or issuing of a license - adds a layer of uncertainty to any tentative agreement an intended generic producer has with the importing country before it seeks a compulsory

\footnotetext{
104 K.M. Gopakumar, \& Tahir Amin, Patents (Amendment) Bill, 2005: A Critique, Economic and Political Weekly, 1503, 1505 (2005) available at http://www.epw.org.in/epw/uploads/articles/447.pdf. (“... the language of Section 83 of the Patent Act reflects the spirit of TRIPS Articles 7 and 8 and Doha Declaration, but the subsequent sections fail to reflect the spirit of Section 83...”). Id. at 1504. 
license from its own government. Generic drug manufacturer seeking compulsory licenses also anticipate increased costs due to the administrative requirements of notification, filing the application, and possible litigation involved. Appeals allowed as part of this process may cause further delay. ${ }^{110}$

Aside from these procedural matters, the capability of the industry to exploit the availability of compulsory licenses, particularly for the post-TRIPS drugs, is another critical issue. The patent experts and business leaders are of the view that merely issuing a compulsory license may not be meaningful because the industry must have the capability to "reverse engineer," particularly the post-TRIPS drugs, ${ }^{111}$ without the cooperation of the patent owner. It may be too simplistic to assume that reading a patent specification will be sufficient to gain the access to a technology for two primary reasons. First, patents do not necessarily disclose the invention to the extent that a person skilled in the art could manufacture it. Undisclosed tacit knowledge is often essential for reproducing an invention. Also, "in the public domain" is not synonymous with "freely available."112 Second, the possibility to take commercial advantage of information disclosed in expired patents may be precluded by multiple overlapping IPR portfolios. ${ }^{113}$

\section{B. Economic Viability}

$110 \quad$ The exporting Member must notify the TRIPS Council of its intention to issue a compulsory license, specifying quantities, destination and distinguishing features of the products. (August 30 Decision, 2 a, b., supra note 5).

111 The industry and experts contend that most of the post-TRIPS drugs will be manufactured through the biotechnological processes which would not be easy to "reverse-engineer."

112 See Stuart Macdonald, Exploring the Hidden Costs of Patents, QUNO Occasional Paper No. 4, Geneva: Quaker United Nations Office (2001) available at http://www.quno.org/geneva/pdf leconomic/Occassional/Compulsory-Licensing.pdf. ("Legal fiction maintains that all the information needed to re-create the invention is contained in the patent specification. The fact is that the specification is forced to refer again and again to other information, information that is in the public domain, which means that it is available somewhere but must be acquired from these sources before the information in the specification can be used. Much of this information will be tacit and un-codified information [i.e. know-how]." Moreover, "the information contained in patent specifications is available only to those who consult them directly, or who pay others more adept at arcane classifications and the language of lawyers to do so.” Id. at 3 (citation omitted). The relevance of tacit knowledge goes further than merely casting doubt on the notion of patents as a reward for disclosing an invention. Even without patents, companies may enjoy a powerful position, since those wishing to acquire tacit knowledge may have no alternative but to license it from holding firms. 
Apart from the concerns raised about the cumbersome and legalistic procedure established for compulsory licensing in the Act and August 30 Decision, the pharmaceutical industry and trade experts also doubt the "commercial viability" of the provisions because of the structure of the Indian pharmaceutical industry.

The Indian pharmaceutical industry is a heterogeneous mixture of firms both organized and unorganized. ${ }^{114}$ Its major constituents are the subsidiaries of the multi-national companies (MNCs) and are a large Indian industry comprising large, medium, and smallsized firms. Althrough it is commonly quoted that there are more than 20,000 manufacturing units,,according to the Expert Committee Report, the number of active units engaged in the production of both bulk-drugs and formulations is not more than $5877 .{ }^{115}$ Of these, only around 300 companies account for over $95 \%$ of the total domestic market, with the rest being marginal players. Thus, only few major generic firms have the capacity to exploit the flexibilities of compulsory licensing. The important question then becomes whether those few firms would be inclined or interested in utilizing the compulsory licensing provisions.

Though India is not likely to lose its vibrant generics industry due to the wide variety of "pre-TRIPS" drugs, the recent trends shows that the future of the Indian industry will be more in line with innovative companies that develop drugs on their own or in cooperation with existing innovative companies in the United States or elsewhere. ${ }^{116}$ With the rise of an innovative industry in India, Indian industry itself could become a powerful force in favor of intellectual property rights. In the post-TRIPS era, the major players of the Indian pharmaceutical industry have started focusing more on the regulated market in the US and West Europe, obviously to reap bigger profits. ${ }^{117}$ The small and middle sized Indian

$114 \quad$ See Shayma Ramani, Who Is Interested In Biotech? R\&D Strategies, Knowledge Base And Market Sales Of Indian Biopharmaceutical Firms, 31 RES. POL'y No 3 (2002).

115 Expert Committee, A Comprehensive Examination of Drug Regulatory Issues, including the Problem of Spurious Drugs, Ministry of Health and Family Welfare, Government of India (2003)

$116 \quad$ Since 1995 , total industry R\&D spending has grown from nearly \$30 million to more than $\$ 495.3$ million in 2005-06. The majority of the industry's R\&D spending is done by 15 companies whose R\&D spending rose to \$192.3 million in 2005 from \$131 million in 2004, representing an increase of 47 percent. See Centre for Monitoring Indian Economy, Prowess (Release 2) (database); R\&D expenditures are expected to gradually rise to between 9 percent and 10 percent of total industry spending by the end of 2007. See Interview with B. Vijayaraghavan, Ranbaxy. For example, in 2005, DRL committed $14 \%$ of its annual sales to R\&D, whereas, Ranbaxy allocated approximately $7 \%$. Others firms with significant R\&D expenditures include Nicholas Piramal, Aurobindo Pharma, and Glenmark Pharma. the poor in the developing and least developed countries. See Interview with Amar Lulla, Cipla. 
pharmaceutical industry may not the resources to exploit the flexibility under the August 30 Decision or the 'parallel imports' provision to reap profits of their own in this manner.

The economic viability of the provision under Section 92A is seriously suspect due to the fact that exporting patented drugs to poor countries in the post-TRIPS era is an activity that entails very thin profit margins. The August 30 obligations mandate the grant of compulsory licenses for a specific purpose, i.e. a specific drug, and for limited duration. All of the production must be exported to the requesting importer country. This puts severe limitations on the ability of generic drug manufacturers to produce post-TRIPS drugs, as it may preclude them from generating more cost-effective economies of scale. Although the need for anti-diversionary provisions to discourage trade diversion in the August 30 Decision cannot be questioned, it limits the ability of producers to achieve economies of scale and maintain sustainable production levels. It also imposes substantial costs on the manufacturer and makes production under compulsory licensing commercially unviable. ${ }^{118}$

The obligation of the exporting country to provide "adequate remuneration" 119 to the patent holder further limits the commercial viability of the generic firms in two ways. First, the generic firms, who are already operating on very thin margins, will have to pay royalties to the patent holder. Second, since the Decision fails to define the term "adequate," it leaves room for interpretation leading to costly legal proceedings in case the patent holder is not satisfied with the "remuneration." It also leaves the patentee with the option threaten with trade sanctions, as the US did in the South African case. ${ }^{120}$ Furthermore, since post-TRIPS drugs are not currently being produced in India, filling a request from an importer country could entail a delay of months to years. To manufacture such pharmaceutical products, firms must spend time and money determining how to produce the product, conducting bioequivalence tests, and possibly performing clinical trials. The pharmaceutical companies may

See supra note 5 , at 2(b).

119

TRIPs, art. 31, para. (h) available at http://www.wto.org/english/docs_e/legal_e/27-trips_04c_e.htm. See also, Decision of General Council, Implementation of Paragraph $\overline{6}$ of the Doha Declaration on the TRIPS Agreement and Public Health, WT/L/540 (Aug. 30, 2003) available at http://www.wto.org/english/tratop_e/trips_e/implem_para6_e.htm. CENTAD 
have to build new production facilities both to manufacture the targeted products for the specified markets, and to comply with the safeguards imposed by the August 30 Decision.

All of these requirements impose additional costs on the generic firms. These costs, compared to perhaps limited benefits, will go into a firm's decision as to whether to make the up-front investment in production.

\section{POLITICAL VIABILITY}

The product patent regime is still in a state of infancy in India and not many instances have come where the compulsory licensing system could have been tested, except the scare of avian influenza in 2005-06. The aftermath of that experience illustrates how the government of India shied away from taking a decisive stand in the matter.

There was a real threat of avian influenza in 2005-06 and the following three options were available to help facilitate production of Tamiflu: ${ }^{121}$

(1) Since only a process patent was granted to $\mathrm{M} / \mathrm{s}$ Roche for the manufacture of Tamiflu in April 2005 and a mail box application concerning a product patent on Tamiflu was pending, the Indian manufacturers could have manufactured generic version of Tamiflu by following a different process. Any infringement of a process patent by other manufacturers was a matter between the process patent holder and the generic manufacturer. There was not any issue/problem from the regulatory point of view. As per the situation at the relevant time, the regulatory office could evaluate and permit a subsequent firm to market a drug if on the basis of mailbox application, a product patent had yet not been considered.

(2) The generic manufacturing firm could approach Roche and obtain a voluntary license.

(3) The Ministry of Health \& Family Welfare could have declared an emergency of national magnitude requiring purchase of the drug immediately. In such an eventuality the Controller could issue the compulsory licenses and the generic manufacturers could have manufactured generic versions of Tamiflu, even if such manufacturing infringed the process patent.

The government was of the view that since at the relevant time (November December 2005) avian flu was non-existent in India among poultry and human population, there was no such health emergency/urgency that warranted the issuance of a compulsory license. The government was also of the view that no other Indian company had the

\footnotetext{
121 The facts that are mentioned in the paragraphs below are based on the actual noting on the Government
} files when it dealt with the crisis in 2005-06. The author had the access to these files. 
technological capabilities manufacture Oseltamivir phosphate (whether by infringing or noninfringing methods) and, therefore, there was no justification to issue any compulsory licenses. Hence, the only viable option was that the government persuade $\mathrm{M} / \mathrm{s}$. Roche to grant a sub-license to M/s Hetero Drugs, a Hyderabad based company, or anybody else who has the capability of manufacturing Oseltamivir phosphate in the desired time frame for Indian consumption. Only through this process and these sources could the government have ensured the availability of the drug by January 31, 2006. The Committee created by the InterMinisterial Task Force to handle the crisis of avian flu was also of the view that decision to buy Tamiflu from M/s Hetreo Drugs should have to be taken after considering whether any existing process patent/product patent would be violated. While legally the violation of the patent would be a matter between patent holder and Hetero, the fact that violation had taken place in executing the supply order from the government of India would cause embarrassment to the government in various international forums. Finally, the government of India took the decision against issuing compulsory licenses, claiming that since not even a single case of infection was reported either in poultry or human beings, there was no national emergency or public health urgency on account of avian influenza.

Surely, one could not state with any certainty that the avian flu would definitely mutate to a form easily communicable among humans. However, the threat was a very real one and if it strikes, it will do so mercilessly - without giving any time for preparation. Because the government of India chose to ignore this fact, it suggests that it might not readily invoke compulsory licensing or government use provisions. It may be relevant to point out here that later in February 2006, avian influenza was reported in Navapur, Nandurbar District, Maharashtra State and Uchchhal, District Surat, and Gujarat State. The case clearly shows that despite having a well laid down legal provisions in the statute book, 'political viability’ and political economy takes precedence over national and public interest.

\section{CONCLUSION}

The foregoing discussion demonstrates that though there are differences in opinion regarding the TRIPS compliance issues vis-à-vis the provisions laid down in the Patent (Amendments) Act of 2005, there are considerable legal options available with the government of India to enable the indigenous generic manufacturers to produce Tamiflu and similar drugs in case of national emergency, public health urgency, and other extraordinary situations. 
The strategy in brief may be outlined as follows:

(1) As a first step, the Indian companies should continue to effectively oppose the mailbox application of Gilead to ensure that no patent is granted. In the meantime, the government can place orders with Ranbaxy and Cipla to manufacture generic version of Tamiflu and create adequate stockpiles. Though Ranbaxy and Cipla claim to have developed an alternative process for manufacturing generic versions of Tami flu, if need be the Controller could issue the compulsory license and the generic manufacturers could manufacture generic versions of Tamiflu even by infringing the process patent.

(2) If a patent is ultimately granted and an adequate stockpile has not been created, the government should first ask Roche whether it can supply the required quantity of the drug at the same rate as that of generic manufacturers. If Roche is agreeable to such option, it should be paid a license fee. This arrangement should continue only while the emergency exists. If Roche does not agree to such terms and conditions, the Government may invoke Section 47 to authorize the creation of stockpiles. ${ }^{122}$

(3) If the avian flu pandemic does occur, the Controller can declare national emergency or public health urgency and issue compulsory licenses under Section 92 to indigenous companies like Ranbaxy and Cipla to manufacture generic versions of Tamiflu. In such an eventuality, the Government can also resort to the provisions under Section 47 and Chapter XVII of the Act.

The concerns and limitations regarding administrative feasibility and economic viability discussed in the section IV may not come in the way of production of Tamiflu. This is because avian flu is an example of a potential public health emergency, where it may be easier to invoke the compulsory licensing or government use provisions. Moreover, since many Governments are stockpiling Tamiflu to cater to a potential pandemic, the magnitude of exports is likely to offset the lower margins per drug sold to developing or least developed countries. However, for other drugs, it is not clear whether the provisions of compulsory licensing will be exploited.

The preceding discussion also points out that the 'access' to drugs does not necessarily depend on the mere existence of legal 'flexibilities.' One must also consider whether such flexibilities will be exploited by the by generic manufacturers and the government. This decision will largely depend upon the 'procedural simplicity,' as well as the 'economic' and 'political' viability.

\footnotetext{
122 See Patent (Amendments) Act, § 47 (2005). It deals with the “Government Use of Inventions”. It dispenses with the need to pay any royalties.
} 
Finally, compulsory licensing in general, and the August 30 rules more specifically, are an untested system. While India has created the legal framework for compulsory licensing making use of the August 30 procedures in the Act, so far they have never been invoked and there is general feeling that the Government may not be politically inclined to issue such compulsory licenses. ${ }^{123}$ In addition to the formal legal regime, in order to grant compulsory licenses for exporting, the government of India must develop the bureaucracy to process and issue compulsory licenses in an efficient and effective manner.

123 Industries perception in view of the response of the government in tackling Avian flu disaster 